\title{
Optimization of solid-state fermentation condition for crude protein enrichment of rice bran using Rhizopus oryzae in tray bioreactor
}

\author{
Andhika Sukma ${ }^{1, *}$, Herawati Oktavianty ${ }^{2}$, Siswo Sumardiono ${ }^{3}$ \\ ${ }^{1}$ Department of Chemical Engineering, Faculty of Engineering, University of Lampung, Jl. Prof. Sumantri Brojonegoro No 1, Bandar \\ Lampung 35145, Indonesia \\ ${ }^{2}$ Department of Agricultural Product Technology, Faculty of Agricultural Technology, INSTIPER, JI. Petung Road No 2, Sleman, Yogyakarta \\ 55281, Indonesia \\ ${ }^{3}$ Department of Chemical Engineering, Faculty of Engineering, Diponegoro University, Jl. Prof. Sudarto No 13, Semarang 50275, Indonesia \\ ${ }^{*}$ Corresponding author: andhika.cahaya@eng.unila.ac.id
}

SUBMITTED 3 July 2020 REVISED 14 October 2020 ACCEPTED 9 January 2021

\begin{abstract}
Enhancement of crude protein content in rice bran with the solid-state fermentation method in tray bioreactor using Rhizopus oryzae FNCC 6011 has been investigated. This research aimed to optimize the fermentation condition using the response surface methodology (RSM). The central composite design (CCD) with three independent variables, including substrate thickness $\left(1\right.$ to $3 \mathrm{~cm}$ ), fermentation temperature $\left(28\right.$ to $32^{\circ} \mathrm{C}$ ), and nutrient concentration of $\mathrm{KH}_{2} \mathrm{PO}_{4}(2$ to $6 \mathrm{~g} / \mathrm{L}$ ) used to determine the crude protein enrichment. The quadratic model has successfully described the effect of variable interactions on responses very well as indicated by the $F$ value and $p$-value are 11.20 and 0.0041 , respectively. The multiple correlation coefficients $\left(\mathrm{R}^{2}\right)$ of 0.9438 indicated that $94.38 \%$ of the model data has approached the actual data with a deviation of $5.62 \%$. The interaction between the variable substrate thickness and the fermentation temperature is the most influential variable on the crude protein enrichment of rice bran, indicated by the highest $F$ value of 24.08 and the lowest $\mathrm{p}$-value of 0.0027 . The highest protein increase of $62.51 \%$ was obtained at $2 \mathrm{~cm}$ substrate thickness, fermentation temperature of $30^{\circ} \mathrm{C}$, and $\mathrm{KH}_{2} \mathrm{PO}_{4}$ concentration of $4 \mathrm{~g} / \mathrm{L}$.
\end{abstract}

KEYWORDS Rice bran; solid-state fermentation; Rhizopus oryzae; response surface methodology

\section{Introduction}

Ritala et al. (2017) has predicted that the global need for protein in 2050, in case of animal protein such as meat and milk, is estimated to reach 1,250 million tons. However, the increase in animal protein needs will not be met continuously due to the low conversion rate of feed into meat and dairy products Ritala et al. (2017). To produce $1 \mathrm{~kg}$ of animal protein, it requires more resources, which are eighteen times more land and ten times more water than to produce $1 \mathrm{~kg}$ of vegetable protein (Sabaté et al. 2014). The protein from fungi is the best protein alternative to meet the global needs in the future since it requires little resources, including land and water. Several fungal strains have been used for the development of protein production, including Aspergillus, Saccharomyces, Fusarium, Candida, Trichoderma, and Rhizopus (Anupama and Ravindra 2001; Nasseri et al. 2011). Rhizopus oryzae is a Zygomycetes filamentous fungus commonly found in Indonesia, Japan, and China to produce food or alcoholic beverages. The fungus $R$. oryzae is very suitable for the production of high protein foods with a low nutrient substrate because its abil- ity to produce polysaccharide-breaking enzymes including cellulase, xylanase, pectinase, and amylase (chui Yu and Hang 1990; Bakir et al. 2001; Hamdy 2006; Chellapandi and Jani 2008; Karmakar and Ray 2011). The content of the essential amino acids lysine, valine, leucine, isoleucine, threonine, arginine, and omega 3 fatty acids in rice bran substrates and various other agro-industrial by-products fermented using $R$. oryzae is known to have increased (Ibarruri and Hernández 2018; Denardi-Souza et al. 2018).

Rice bran is the outermost layer of rice grains that are released during the rice milling process. Rice bran is used as an animal feed with a high proportion of $90 \%$ and the remainder is extracted to produce rice bran oil (Schramm et al. 2007). Besides containing macronutrients such as protein, fat, and dietary fibre, rice bran is also known to contain micronutrients such as minerals and vitamin E, so it is suitable to be used as a substrate in the production of high protein foods (Xu et al. 2001). Utilization of rice bran as a high protein food is still rare. Hence, the substitution of food is a maximum of $10 \%$ due to the insoluble fibre content of rice bran $>20 \%$ consist- 
ing of cellulose and hemicellulose in almost the same ratio so that it affects the aroma, flavour, and texture of food (Qi et al. 2015). One of the attempts for increasing rice bran protein content while decreasing insoluble fibre content is by solid-state fermentation. This technique has been proven to produce higher yields lower energy, less wastewater, and environmentally friendly compared to submerged fermentation (Pandey 2003; Martins et al. 2011). Fermented rice bran by $R$. oryzae with solid-state fermentation method has been shown to have increased protein content, aroma, flavour, and texture so that it can be widely used as food (da Silveira and Badiale-Furlong 2009; Oliveira et al. 2010; Sukma et al. 2018).

The response surface methodology (RSM) is used to model a certain number of variables aimed at optimizing the response. To describe biochemical processes using mathematical models, RSM provides accurate results in a short time with a few experiments (Baş and Boyaci 2007; Firatligil-Durmus and Evranuz 2010). RSM has been used in the fermentation process, among others, to produce Lasparaginase, laccase, and protease enzymes with high productivity through several influential variables so that the production process becomes more efficient (da Cunha et al. 2018; Sondhi and Saini 2019; Suberu et al. 2019). There are limited studies on the optimization of crude protein enhancement in rice bran using the $R$. oryzae fungus with the RSM method, so it is not known the exact parameters for scale-up production. Previous research only study on the kinetics of rice bran fermentation where there was an increase in crude protein content of rice bran by $58.5 \%$ after $120 \mathrm{~h}$ of fermentation using $R$. oryzae (Sukma et al. 2018). To produce high crude protein on a large scale and reduce production costs, studies are needed to optimize the operating conditions for fermentation. This information is needed as a basis for consideration for developing rice bran on a commercial scale to be widely applied as a functional food ingredient. Therefore, this study aims to optimize the enrichment crude protein of rice bran using $R$. oryzae with the solid-state fermentation method. The variables to be investigated are substrate thickness, fermentation temperature, and nutrient concentration of $\mathrm{KH}_{2} \mathrm{PO}_{4}$. These parameters affect the mass and heat transfer rates in the fermentation medium, the biomass growth rate, and the amount of product on a larger production scale (Mitchell et al. 2006).

\section{Materials and Methods}

\subsection{Rice Bran}

The material used was fresh rice bran obtained from the rice milling machine in Teter Village, Simo Subdistrict, Boyolali Regency, Central Java, Indonesia. To eliminate the rice husk and broken rice that follow, rice bran was sieved using a 35 mesh sieve (Retsch AS200, Haan, Germany). The rice bran was put into a $3 \mathrm{~L}$ polypropylene box and stored at $4{ }^{\circ} \mathrm{C}$ to prevent enzymatic reactions (Sukma et al. 2018).

\subsection{Inoculum Preparation}

$R$. oryzae (FNCC 6011) was obtained from the Food and Nutrition Culture Collection (FNCC) of Food and Nutrition PAU, Universitas Gadjah Mada, Indonesia. Culture in ampoules was transferred into a petri dish containing potato dextrose agar (PDA, Merck KGaA, Darmstadt, Germany) and incubated for seven days at $30^{\circ} \mathrm{C}$ (Oliveira et al. 2010). Fungal culture and formed spores were taken using sterile tweezers and dissolved in $100 \mathrm{~mL}$ of Tween $80(0.2 \%)$ solution (Merck KGaA, Darmstadt, Germany) to produce spore suspension. Spore concentration was measured using the total plate count (TPC) method. The spore suspension was put into a $100 \mathrm{~mL}$ sterile glass bottle and stored at $4{ }^{\circ} \mathrm{C}$ until used.

\subsection{Fermentation}

Fermentation was carried out with the solid-state fermentation method using the tray bioreactor (plastic material, unperforated, unagitated, and unmixed). The tray bioreactor with a size of $21 \mathrm{~cm} \times 12 \mathrm{~cm} \times 4 \mathrm{~cm}, 16 \mathrm{~cm} \times 8$ $\mathrm{cm} \times 4 \mathrm{~cm}$, and $14 \mathrm{~cm} \times 6 \mathrm{~cm} \times 5 \mathrm{~cm}$ was used in this study. Each $100 \mathrm{~g}$ of rice bran was put into the tray bioreactor of different sizes so that the thickness of the rice bran substrates 1,2 , and $3 \mathrm{~cm}$ was produced. The tray bioreactor containing rice bran was sterilized in an autoclave (Hirayama HVE-50, Tokyo, Japan) at $121^{\circ} \mathrm{C}$ for $30 \mathrm{~min}$. Two grams of sample was taken from each tray bioreactor for protein content analysis followed by an additional of 45 $\mathrm{mL}$ of nutrient solution $\left(\mathrm{KH}_{2} \mathrm{PO}_{4} 2\right.$, 4, and $6 \mathrm{~g} / \mathrm{L} ; \mathrm{MgSO}_{4}$ $1 \mathrm{~g} / \mathrm{L}$; and $\left(\mathrm{NH}_{4}\right)_{2} \mathrm{SO}_{4} 8 \mathrm{~g} / \mathrm{L}$ in $0.4 \mathrm{~N} \mathrm{HCl}$ ) (Merck KGaA, Darmstadt, Germany) into tray bioreactor which contains rice bran substrate. Rhizopus oryzae spore suspension was added to the rice bran substrate with an initial concentration of $4 \times 10^{6}$ spores/g of rice bran (Oliveira et al. 2010). The sterile distilled water was added to the rice bran substrate until the moisture content becomes 55\% (Yunus et al. 2015). The rice bran substrate was further incubated in an incubator (Heraeus B6060, Hanau, Germany) for $120 \mathrm{~h}$ with varying temperatures 28,30 , and $32{ }^{\circ} \mathrm{C}$ using forced air circulation. Samples were taken after fermentation was completed for analysis of protein content.

\subsection{Protein Content Determination}

The total protein content can be described as total nitrogen content using the Kjeldahl method (AOAC. 2000, no. 955.04C). The conversion factor used is 6.25 (Oliveira et al. 2010). The increase in protein content is calculated using the following equation.

$$
P E=\frac{(F R B-U F R B)}{U F R B} \times 100 \%
$$

Where, PE : Protein Enrichment (\%), UFRB : Protein content of unfermented rice bran (\%), FRB : Protein content of fermented rice bran (\%).

\subsection{Experimental design}

Experimental design of protein enrichment in rice bran by $R$. oryzae using the solid-state fermentation method was 
obtained based on the determination of influential variables such as substrate thickness, fermentation temperature, and nutrient concentration $\mathrm{KH}_{2} \mathrm{PO}_{4}$. These parameters were chosen because they are considered the most important in the process of protein enrichment by the solid-state fermentation method. Central composite design (CCD) at three levels $(-1,0$, and +1$)$ designated as high, medium, and low was used for this study. This study was conducted using the Design Expert 7.0.0 program. Central composite design (CCD) has been used to test the effect of interaction between the variable in the fermentation process. This method is also very suitable for matching quadratic surfaces, for optimizing parameters that affect the minimum number of experiments, and the ability to predict model data with sufficient accuracy compared to Box-Benkhen, Plackett-Burman, and Taguchi designs (Myers et al. 2002; Rakić et al. 2014; Marrubini et al. 2020).

Three critical steps to carry out optimization based on RSM (response surface methodology) were experimental design with a statistical approach, mathematical modeling, and prediction of responses, which then produced the desired model. Mathematical equation models were tested using an analysis of variance (ANOVA) with a 99\% confidence level. The output produced by RSM was contour images and 3D graphics that show the optimal variables and the variables that most influence protein enrichment. According to CCD, the total number of combination experiments is $2^{\mathrm{k}}+2 \mathrm{k}+\mathrm{n}_{\mathrm{c}}$, where $\mathrm{k}$ is the total number of independent variables and $n_{c}$ is the number of experiments at the center point. The combination of different variables produces 16 trial runs consisting of 8 factorial points (1-8), 6 axial points (9-14), and 2 repetitions at the center point $(15,16)$. The second-order model was created to test the interaction of independent variables on response. The basis for the formation of the polynomial equation is shown in Equation 1, where $Y$ is the response, $\beta_{0}$ is the intercept, $\beta_{i}$ is a linear coefficient, $\beta_{i i}$ is the quadratic coefficient, $\beta_{i j}$ is the interaction coefficient, and $\mathrm{X}_{i} \mathrm{X}_{j}$ is the independent variable (Singh et al. 2020).

$$
Y=\beta_{0}+\sum_{i=1}^{3} \beta_{i} X_{i}+\sum_{i=1}^{3} \beta_{i i} X_{i}^{2}+\ldots \ldots \sum_{i<j} \beta_{i j} X_{i} X_{j}
$$

TABLE 1 Experimental range and coded levels of process variables for crude protein enrichment.

\begin{tabular}{llll}
\hline Process variables & \multicolumn{3}{l}{ Range and Levels } \\
& -1 & 0 & 1 \\
Substrate thickness $\left(\mathrm{X}_{1}\right)$ & 1 & 2 & 3 \\
Fermentation temperature $\left(\mathrm{X}_{2}\right)$ & 28 & 30 & 32 \\
$\begin{array}{l}\text { Nutrient concentration of } \mathrm{KH}_{2} \mathrm{PO}_{4} \\
\left(\mathrm{X}_{3}\right)\end{array}$ & 2 & 4 & 6 \\
\hline
\end{tabular}

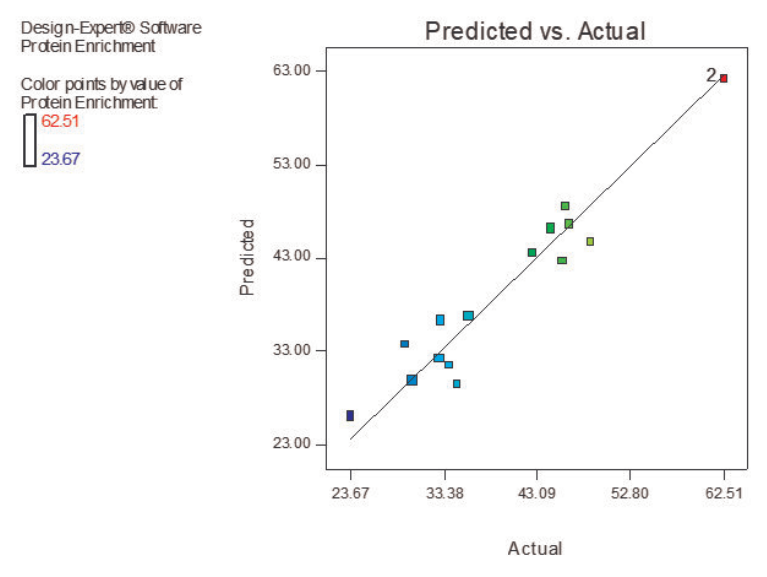

FIGURE 1 The correlation coefficient between model data and experimental data.

\section{Results and Discussion}

\subsection{Central composite design (CCD)}

The response of protein enrichment (\%) as a function of substrate thickness, fermentation temperature, and nutrient concentration of $\mathrm{KH}_{2} \mathrm{PO}_{4}$ has been evaluated using CCD. The study design and response are shown in Table 2. Mathematical models are obtained using Design Expert 7.0.0. The crude protein content in rice bran before fermentation has been obtained at $12.59 \%$ so that the crude protein enrichment as a response is determined based on Equation 1.

Analysis of variance (ANOVA) was carried out using Design Expert 7.0.0 to evaluate the effect of interactions between variables. Table 3 shows the ANOVA for the quadratic equation model on the response surface (partial sum of squares) and the response for protein enrichment. From Table 3 it can be seen that the $\mathrm{F}$ value and prob > $\mathrm{F}$ are 11.20 and 0.0041 , respectively, indicating that the model is significant. The multiple correlation coefficients $\left(\mathrm{R}^{2}\right)$ of 0.9438 indicated that $94.38 \%$ of the model data had approached the actual data and only a deviation of $5.62 \%$ of the variables was used. The model indicates to be accurate if the $\mathrm{R}^{2}$ value exceeds $70 \%$. Therefore, it can be concluded that the value estimated by the model is close to the value obtained from the experimental results (Haaland 1989). The most dominant factor in this study was the interaction between thickness substrate and fermentation temperature with the highest $F$ value of 24.08 and the lowest p-value of 0.0027 . The regression line in Figure 1 shows the best prediction of the predicted value against the actual value. In fact, there is always a residual value which is a deviation of certain points from the regression line (predictive value) (Anggoro et al. 2019).

Experimental equations of protein enrichment as a function of substrate thickness, fermentation temperature, and nutrients concentration of $\mathrm{KH}_{2} \mathrm{PO}_{4}$ are presented below: 


$$
\begin{array}{r}
\text { Protein Enrichment }(\%)=-2298.1399+154.8928 X_{1} \\
+144.2289 X_{2}+20.5514 X_{3} \\
-3.6337 X_{1} X_{2}-0.4562 X_{1} X_{3} \\
-0.2931 X_{2} X_{3}-10.7274 X_{1}^{2} \\
-2.2642 X_{2}^{2}-1.3127 X_{3}^{2}
\end{array}
$$

\subsection{Response surface methodology (RSM)}

The relationship between responses and variables is described using response surfaces by following the model that has been made. Figures 2, 3, and 4 show the interactions between variables on the response of protein enrichment using 3-D graphs.

Figure 2 shows the interaction variable between a substrate thickness and fermentation temperature on the protein enrichment of rice bran. The interaction variable between the substrate thickness and the fermentation tem- perature is the most influential factor to increase the protein content of rice bran. Rice bran substrate during the fermentation process has an increase in temperature this is due to the metabolic activity of the fungus $R$. oryzae. The highest protein enrichment of rice bran was obtained at the substrate thickness of $2 \mathrm{~cm}$ and the fermentation temperature of $30{ }^{\circ} \mathrm{C}$ with the nutrient concentration of $\mathrm{KH}_{2} \mathrm{PO}_{4} 4 \mathrm{~g} / \mathrm{L}$ (Mitchell et al. 2006; Chen 2013). In this condition, the organic compound produced by $R$. oryzae which consists of amino acids and polysaccharide degrading enzymes such as cellulase, xylanase, pectinase and, amylase reach a maximum limit (chui Yu and Hang 1990; Bakir et al. 2001; Chellapandi and Jani 2008; Karmakar and Ray 2011). In addition to extracellular compounds, the metabolic products of $R$. oryzae are water vapour and carbon dioxide gas. These gases will diffuse from the sub-

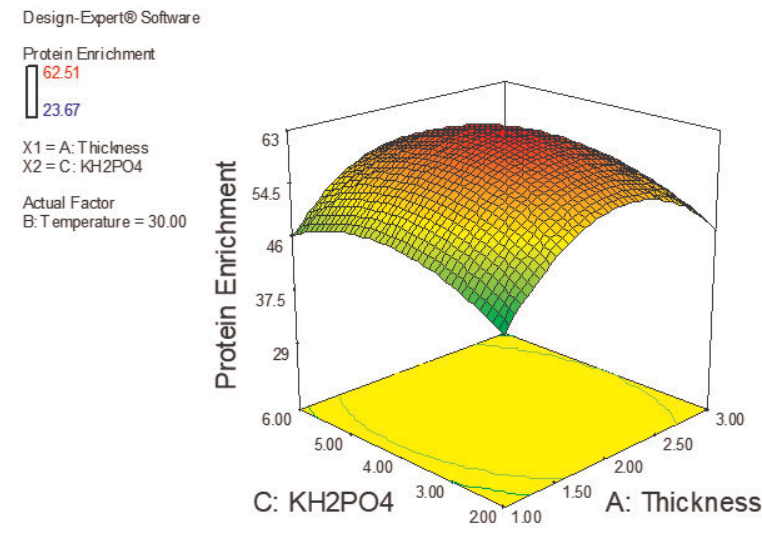

FIGURE 3 3D graph of the effect of substrate thickness and nutrients concentration of $\mathrm{KH} 2 \mathrm{PO} 4$ on protein enrichment.

\begin{tabular}{|c|c|c|c|c|c|}
\hline Run & Substrate Thickness $(\mathrm{cm})$ & Fermentation Temperature $\left({ }^{\circ} \mathrm{C}\right)$ & Nutrient $\mathrm{KH}_{2} \mathrm{PO}_{4}(\mathrm{~g} / \mathrm{L})$ & Crude Protein Enrichment (\%) & Crude Protein (\% \\
\hline 1 & 2.00 & 30.00 & 7.36 & 45.99 & $18.38 \pm 0,06$ \\
\hline 2 & 1.00 & 28.00 & 2.00 & 23.67 & $15.57 \pm 0,12$ \\
\hline 3 & 3.68 & 30.00 & 4.00 & 29.39 & $16.29 \pm 0,08$ \\
\hline 4 & 1.00 & 32.00 & 6.00 & 42.57 & $17.95 \pm 0,06$ \\
\hline 5 & 3.00 & 28.00 & 6.00 & 46.47 & $18.44 \pm 0,07$ \\
\hline 6 & 2.00 & 30.00 & 4.00 & 62.51 & $20.46 \pm 0,09$ \\
\hline 7 & 1.00 & 28.00 & 6.00 & 33.92 & $16.86 \pm 0,15$ \\
\hline 8 & 3.00 & 28.00 & 2.00 & 48.61 & $18.71 \pm 0,12$ \\
\hline 9 & 2.00 & 30.00 & 4.00 & 62.51 & $20.46 \pm 0,09$ \\
\hline 10 & 3.00 & 32.00 & 2.00 & 32.88 & $16.73 \pm 0,09$ \\
\hline 11 & 0.32 & 30.00 & 4.00 & 30.10 & $16.38 \pm 0,10$ \\
\hline 12 & 2.00 & 30.00 & 0.64 & 44.48 & $18.19 \pm 0,11$ \\
\hline 13 & 2.00 & 33.36 & 4.00 & 32.96 & $16.74 \pm 0,08$ \\
\hline 14 & 1.00 & 32.00 & 2.00 & 45.75 & $18.35 \pm 0,05$ \\
\hline 15 & 2.00 & 26.64 & 4.00 & 35.98 & $17 \cdot 12 \pm 0,12$ \\
\hline 16 & 3.00 & 32.00 & 6.00 & 34.79 & $16.97 \pm 0,15$ \\
\hline
\end{tabular}

FIGURE 2 3D graph of the effect of substrate thickness and fermentation temperature on protein enrichment.

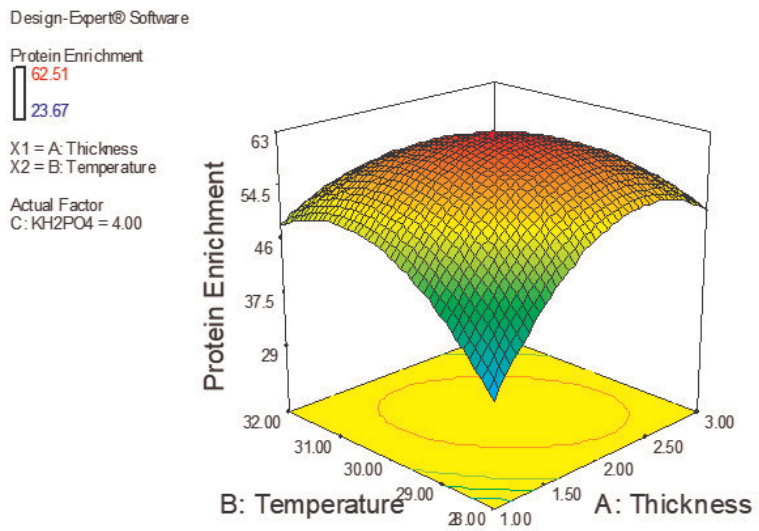

TABLE 2 Experimental design and response using CCD. 
strate into the environment consequently the water content of the substrate will decrease. In this study, the incubator was set with varying temperatures of 28,30 , and $32{ }^{\circ} \mathrm{C}$ using forced air circulation. The thinner the substrate layer, the faster the rice bran substrate temperature loss, resulting in the rate of transfer of $\mathrm{O}_{2}, \mathrm{CO}_{2}$, and $\mathrm{H}_{2} \mathrm{O}$ gases will be greater and the water content of the substrate decreases rapidly, this affects the speed of excretion and activity of these enzymes. Likewise, if the substrate is getting thicker, the substrate temperature will increase rapidly, this causes the growth of the fungus $R$. oryzae to be inhibited, as well as the rate of transfer of $\mathrm{O}_{2}, \mathrm{CO}_{2}$, and $\mathrm{H}_{2} \mathrm{O}$ gases to be inhibited (Chen 2013; Mitchell et al. 2006; Dutt and Kumar 2014).

$R$. oryzae generally grow in the temperature range of 30-35 ${ }^{\circ} \mathrm{C}$, with a maximum survival limit to temperatures of $45^{\circ} \mathrm{C}$ (Lennartsson et al. 2014). Rice bran is known to contain insoluble fibre $>20 \%$ consisting of cellulose and hemicellulose. To convert these complex compounds into simpler compounds, cellulase and xylanase enzymes are needed. The activity of cellulase and xylanase enzymes in the agro-industrial substrate containing lignocellulose by solid-state fermentation method is known to be maximal at $30{ }^{\circ} \mathrm{C}$ (Ezeilo et al. 2020). Rice bran is an agro-industrial waste, so that the optimum temperature for breaking down cellulose and hemicellulose into simple sugars for the formation of biomass and protein is at $30{ }^{\circ} \mathrm{C}$.

The addition of potassium and phosphate elements in fermentation media is expected to be a cofactor in several enzymes produced by microbes to degrade polysaccharides into monosaccharide and as forming elements of nucleic acids, nucleotides, and phospholipids in $R$. oryzae

TABLE 3 ANOVA for the response surface quadratic model, Responses: protein enrichment (\%).

\begin{tabular}{llllll}
\hline Source & $\begin{array}{l}\text { Sum of } \\
\text { Squares }\end{array}$ & DF & $\begin{array}{l}\text { Mean } \\
\text { Square }\end{array}$ & F Value & Prob >F \\
\hline Model & 1764.64 & 9 & 196.40 & 11.20 & 0.0041 \\
A (Thickness) & 17.92 & 1 & 17.92 & 1.02 & 0.3511 \\
B (Temperature) & 0.23 & 1 & 0.23 & 0.013 & 0.9132 \\
C (KH $\left.{ }_{2} \mathrm{PO}_{4}\right)$ & 6.44 & 1 & 6.44 & 0.37 & 0.5667 \\
$\mathrm{AB}$ & 422.53 & 1 & 422.53 & 24.08 & 0.0027 \\
$\mathrm{AC}$ & 6.66 & 1 & 6.66 & 0.38 & 0.5604 \\
$\mathrm{BC}$ & 11.00 & 1 & 11.00 & 0.63 & 0.4586 \\
$\mathrm{~A}^{2}$ & 1066.90 & 1 & 1066.09 & 60.77 & 0.0002 \\
$\mathrm{~B}^{2}$ & 759.91 & 1 & 759.91 & 43.32 & 0.0006 \\
$\mathrm{C}^{2}$ & 255.43 & 1 & 255.43 & 14.56 & 0.0088 \\
Residual & 105.26 & 6 & 17.54 & & \\
Lack of fit & 105.26 & 5 & 21.05 & & \\
Pure Error & 0.000 & 1 & 0.000 & & \\
Cor Total & 187.90 & 15 & & & \\
\hline Std.Dev. & & \multicolumn{5}{c}{4.19} & \\
$\mathrm{R}^{2}$ & & \multicolumn{5}{c}{0.9438} & \\
Adjusted $\mathrm{R}^{2}$ & & \multicolumn{5}{c}{0.8595} & \\
\hline
\end{tabular}

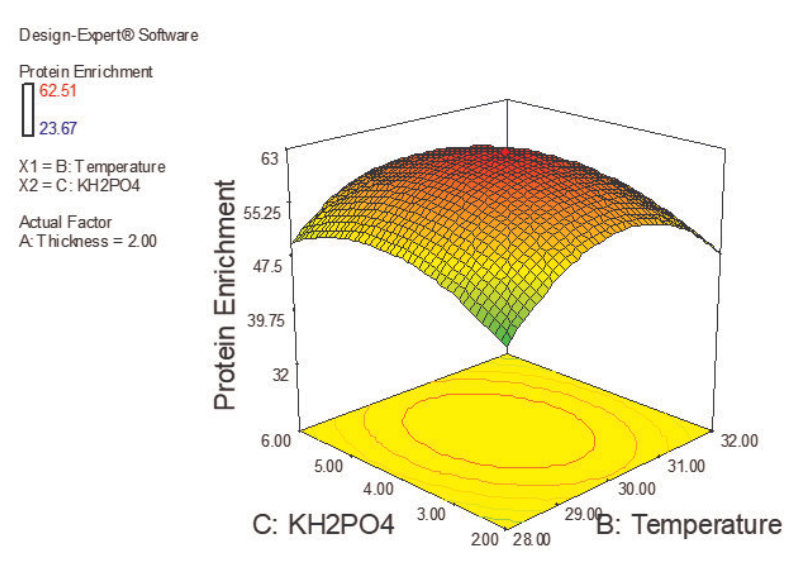

FIGURE 4 3D graph of the effect of temperature fermentation and nutrient concentration $\mathrm{KH}_{2} \mathrm{PO}_{4}$ on protein enrichment.

cells (Shuler and Kargi 2002). Phosphate is also used as an energy source for microbes, where the more phosphate is obtained, the ATP (adenosine triphosphate) formed during the fermentation process will also increase. ATP is used in the process of cell metabolism, among others, for the growth and development of biomass and the excretion of organic compounds out of cells (Rubio-Arroyo et al. 2011). Increasing nutrient concentration of $\mathrm{KH}_{2} \mathrm{PO}_{4}$ from $2 \mathrm{~g} / \mathrm{L}$ to $4 \mathrm{~g} / \mathrm{L}$ has been shown to increase protein content in the medium, while the addition of nutrients up to $6 \mathrm{~g} / \mathrm{L}$, an increase in protein content decreases. The phenomenon is caused by the elements of potassium and phosphate used for the initial phase of the growth of biomass cells. The more $\mathrm{KH}_{2} \mathrm{PO}_{4}$ biomass cell growth at the beginning of fermentation the faster it is so that the results of cell metabolism are preferred for the growth and development of biomass cells, compared to the excretion of organic compounds (Mohammadi et al. 2013; Das and Ghosh 2014; Deepthi and Satheeshkumar 2017).

Based on these results, it can be seen that the $\mathrm{KH}_{2} \mathrm{PO}_{4}$ concentration of $4 \mathrm{~g} / \mathrm{L}$ is the best choice in the process of rice bran fermentation using the fungus $R$. oryzae. Enhancement of protein content in this study was $62.51 \%$, indicating that it is $6.85 \%$ higher than previous studies using the same substrate. The same phenomenon also occurs in the fermentation of glucose into ethanol using Mucor indicus, where the highest ethanol yield is obtained by using $\mathrm{KH}_{2} \mathrm{PO}_{4}$ concentration of $3.5 \mathrm{~g} / \mathrm{L}$, the higher the $\mathrm{KH}_{2} \mathrm{PO}_{4}$ concentration the greater the energy lost during the fermentation process this makes the metabolic process to be inefficient (Aghbashlo et al. 2017). Most bacteria and fungi can live and carry out metabolic processes well at $\mathrm{KH}_{2} \mathrm{PO}_{4}$ concentrations reaching $5 \mathrm{~g} / \mathrm{L}$ (Vogel and Todaro 2014).

The results showed that the variables selected for the fermentation process affected the crude protein enrichment in rice bran. The interaction between the variable substrate thickness and fermentation temperature has the strongest effect in this experiment. This is the focus of 
attention for further studies when using the solid-state fermentation method to increase the crude protein content in materials, especially for scale-up production on a commercial scale. Based on the optimization results using RSM, the best results were obtained using the variable thickness of the substrate $2 \mathrm{~cm}$, fermentation temperature $30^{\circ} \mathrm{C}$, and the nutrient concentration of $\mathrm{KH}_{2} \mathrm{PO}_{4}$ of $4 \mathrm{~g} / \mathrm{L}$.

\section{Conclusions}

Response surface methodology with central composite design has succeeded in optimizing the increase in rice bran protein content using Rhizopus oryzae with the solid-state fermentation method. The highest increase in protein content of $62.51 \%$ was obtained with the variable substrate thickness of $2 \mathrm{~cm}$, fermentation temperature of $30^{\circ} \mathrm{C}$, and $\mathrm{KH}_{2} \mathrm{PO}_{4}$ nutrient concentration of $4 \mathrm{~g} / \mathrm{L}$. The interaction between the variable substrate thickness and fermentation temperature is the most dominant factor in this study. To increase the production of rice bran protein on a large scale, we recommend expanding the tray size or increasing the number of trays while maintaining the thickness of the substrate by $2 \mathrm{~cm}$.

\section{Authors' contributions}

AS, SS designed the study. AS carried out the laboratory work. HO analyzed the data. AS, HO, SS wrote the manuscript. All authors read and approved the final version of the manuscript.

\section{Competing interests}

The author declare that they have no competing interest.

\section{References}

Aghbashlo M, Tabatabaei M, Karimi K, Mohammadi M. 2017. Effect of phosphate concentration on exergeticbased sustainability parameters of glucose fermentation by Ethanolic Mucor indicus. Sustain Prod Consum. 9:28-36. doi:10.1016/j.spc.2016.06.004.

Anggoro DD, Oktavianty H, Kurniawan BP, Daud R. 2019. Optimization of glycerol monolaurate (Gml) synthesis from glycerol and lauric acid using dealuminated zeolite Y catalyst. Jurnal Teknologi. 81(4):133141. doi:10.11113/jt.v81.13511.

Anupama, Ravindra P. 2001. Studies on production of single cell protein by Aspergillus niger in solid state fermentation of rice bran. Braz Arch Biol Technol. 44(1):79-88. doi:10.1590/S151689132001000100011.

Baş D, Boyaci IH. 2007. Modeling and optimization i: Usability of response surface methodology. J Food Eng. 78(3):836-845. doi:10.1016/j.jfoodeng.2005.11.024.
Bakir U, Yavascaoglu S, Guvenc F, Ersayin A. 2001. An endo- $\beta$-1,4-xylanase from Rhizopus oryzae: Production, partial purification and biochemical characterization. Enzyme Microb Technol. 29(6-7):328-334. doi:10.1016/S0141-0229(01)00379-9.

Chellapandi P, Jani HM. 2008. Production of endoglucanase by the native strains of Streptomyces isolates in submerged fermentation. Braz J Microbiol. 39(1):122-127. doi:10.1590/S151783822008000100026.

Chen H. 2013. Modern solid state fermentation: Theory and practice. Dordrecht: Springer. doi:10.1007/97894-007-6043-1_1.

chui Yu R, Hang YD. 1990. Amylolytic enzyme production by Rhizopus oryzae grown on agricultural commodities. World Journal of Microbiology and Biotechnology 6(1):15-18. doi:10.1007/BF01225348.

da Cunha MC, Silva LC, Sato HH, de Castro RJS. 2018. Using response surface methodology to improve the L-asparaginase production by Aspergillus niger under solid-state fermentation. Biocatal Agric Biotechnol. 16:31-36. doi:10.1016/j.bcab.2018.07.018.

da Silveira CM, Badiale-Furlong E. 2009. Sperathe effects of solid-state fermentation in the functional properties of defatted rice bran and wheat bran. Braz Arch Biol Technol. Biol. Technol. 52(6):1555-1562. doi:10.1590/S1516-89132009000600027.

Das S, Ghosh U. 2014. Effect of nutritional supplementation of solid state fermentation medium on biosynthesis of phytase from Aspergillus niger NCIM 612. J Sci Ind Res. 73(9):593-597.

Deepthi S, Satheeshkumar K. 2017. Effects of major nutrients, growth regulators and inoculum size on enhanced growth and camptothecin production in adventitious root cultures of Ophiorrhiza mungos L. Biochem Eng J. 117:198-209. doi:10.1016/j.bej.2016.10.016.

Denardi-Souza T, Massarolo KC, Tralamazza SM, Badiale-Furlong E. 2018. Monitoreo de la biomasa micótica modificada por Rhizopus oryzae en relación con el perfil de aminoácidos y ácidos grasos esenciales de harina de soya (soja), trigo y arroz. CYTA-J Food. 16(1):156-164. doi:10.1080/19476337.2017.1359676.

Dutt D, Kumar A. 2014. Optimization of cellulase production under solid-state fermentation by Aspergillus flavus (AT-2) and Aspergillus niger (AT-3) and its impact on stickies and ink particle size of sorted office paper. Cellul Chem Technol. 48(3-4):285-298.

Ezeilo UR, Wahab RA, Mahat NA. 2020. Optimization studies on cellulase and xylanase production by Rhizopus oryzae UC2 using raw oil palm frond leaves as substrate under solid state fermentation. Renewable Energy 156:1301-1312. doi:10.1016/j.renene.2019.11.149.

Firatligil-Durmus E, Evranuz O. 2010. Response surface methodology for protein extraction 
optimization of red pepper seed (Capsicum frutescens). LWT-Food Sci Technol. 43(2):226-231. doi:10.1016/j.lwt.2009.08.017.

Haaland PD. 1989. Experimental Design in Biotechnology. CRC Press. doi:10.1201/9781003065968.

Hamdy HS. 2006. Purification and characterization of the pectin lyase secreted within the macerating fluid of Rhizopus oryzae (Went \& Prinsen Geerligs) grown on orange peel. Indian J Biotechnol. 5(3):284-291.

Ibarruri J, Hernández I. 2018. Rhizopus oryzae as Fermentation Agent in Food Derived Subproducts. Waste Biomass Valorization 9(11):21072115. doi:10.1007/s12649-017-0017-8.

Karmakar M, Ray R. 2011. Current Trends in Research and Application of Microbial Cellulases. Research Journal of Microbiology 6(1):41-53. doi:10.3923/jm.2011.41.53.

Lennartsson P, Taherzadeh M, Edebo L. 2014. Rhizopus. In: CA Batt, ML Tortorello, editors, Encyclopedia of Food Microbiology (Second Edition). Oxford: Academic Press, second edition edition. p. $284-$ 290. doi:https://doi.org/10.1016/B978-0-12-3847300.00391-8.

Marrubini G, Dugheri S, Cappelli G, Arcangeli G, Mucci N, Appelblad P, Melzi C, Speltini A. 2020. Experimental designs for solid-phase microextraction method development in bioanalysis: A review. Anal Chim Acta. 1119:77-100. doi:10.1016/j.aca.2020.04.012.

Martins S, Mussatto SI, Martínez-Avila G, MontañezSaenz J, Aguilar CN, Teixeira JA. 2011. Bioactive phenolic compounds: Production and extraction by solid-state fermentation. A review 29(3):365-373. doi:10.1016/j.biotechadv.2011.01.008.

Mitchell DA, Krieger N, Berovič M. 2006. Solid-state fermentation bioreactors. Heidelberg: Springer. doi:10.1007/3-540-31286-2.

Mohammadi M, Zamani A, Karimi K. 2013. Effect of phosphate on glucosamine production by ethanolic fungus Mucor indicus. Appl Biochem Biotechnol. 171(6):1465-1472. doi:10.1007/s12010-013-0440-7.

Myers RH, Montgomery DC, Anderson-Cook C. 2002. Process and product optimization using designed experiments, volume 2. New York: John Wiley \& Sons.

Nasseri AT, Rasoul-Amini S, Morowvat MH, Ghasemi Y. 2011. Single cell protein: Production and process. Am J Food Technol. 6(2):103-116. doi:10.3923/ajft.2011.103.116.

Oliveira MdS, Feddern V, Kupski L, Cipolatti EP, Badiale-Furlong E, De Souza-Soares LA. 2010. Physico-chemical characterization of fermented rice bran biomass. CYTA-J Food. 8(3):229-236. doi:10.1080/19476330903450274.

Pandey A. 2003. Solid-state fermentation. Biochem Eng J. 13(2-3):81-84. doi:10.1016/S1369-703X(02)001213.

Qi J, Li Y, Yokoyama W, Majeed H, Masamba KG, Zhong F, Ma J. 2015. Cellulosic fraction of rice bran fi- bre alters the conformation and inhibits the activity of porcine pancreatic lipase. Journal of Functional Foods 19:39-48. doi:10.1016/j.jff.2015.09.012.

Rakić T, Kasagić-Vujanović I, Jovanović M, JančićStojanović B, Ivanović D. 2014. Comparison of Full Factorial Design, Central Composite Design, and Box-Behnken Design in Chromatographic Method Development for the Determination of Fluconazole and Its Impurities. Analytical Letters 47(8):13341347. doi:10.1080/00032719.2013.867503.

Ritala A, Häkkinen ST, Toivari M, Wiebe MG. 2017. Single cell protein-state-of-the-art, industrial landscape and patents 2001-2016. Front Microbiol. 8(OCT). doi:10.3389/fmicb.2017.02009.

Rubio-Arroyo MF, Vivanco-Loyo P, Juárez M, Poisot M, Ramírez-Galicia G. 2011. Bio-ethanol obtained by fermentation process with continuous feeding of yeast. J Mex Chem Soc. 55(4):242-245.

Sabaté J, Sranacharoenpong K, Harwatt H, Wien M, Soret S. 2014. The environmental cost of protein food choices. Public Health Nutr. 18(11):2067-2073. doi:10.1017/S1368980014002377.

Schramm R, Abadie A, Hua N, Xu Z, Lima M. 2007. Fractionation of the rice bran layer and quantification of vitamin E, oryzanol, protein, and rice bran saccharide. J Biol Eng. 1. doi:10.1186/1754-1611-1-9.

Shuler ML, Kargi F. 2002. Bioprocess engineering: Basic concepts. New Jersey: Prentice-Hall International Inc. doi:10.1016/0168-3659(92)90106-2.

Singh RS, Chauhan K, Kaur K, Pandey A. 2020. Statistical optimization of solid-state fermentation for the production of fungal inulinase from apple pomace. Bioresour Technol Rep. 9. doi:10.1016/j.biteb.2019.100364.

Sondhi S, Saini K. $2019 . \quad$ Response surface based optimization of laccase production from Bacillus sp. MSK-01 using fruit juice waste as an effective substrate. Heliyon. 5(5). doi:10.1016/j.heliyon.2019.e01718.

Suberu Y, Akande I, Samuel T, Lawal A, Olaniran A. 2019. Optimization of protease production in indigenous Bacillus species isolated from soil samples in Lagos, Nigeria using response surface methodology. Biocatal Agric Biotechnol. 18. doi:10.1016/j.bcab.2019.01.049.

Sukma A, Jos B, Sumardiono S. 2018. Kinetic of biomass growth and protein formation on rice bran fermentation using Rhizopus oryzae. In: MATEC Web of Conferences, volume 156. doi:10.1051/matecconf/201815601023.

Vogel HC, Todaro CM. 2014. Fermentation and Biochemical Engineering Handbook: Principles, Process Design, and Equipment: Third Edition. Oxford: Elsevier Inc. doi:10.1016/C2011-0-05779-4.

Xu Z, Hua N, Samuel Godber J. 2001. Antioxidant activity of tocopherols, tocotrienols, and $\gamma$-oryzanol components from rice bran against cholesterol oxidation accelerated by 2,2'-azobis(2-methylpropionamidine) 
dihydrochloride. Journal of Agricultural and Food Chemistry 49(4):2077-2081. doi:10.1021/jf0012852. Yunus FuN, Nadeem M, Rashid F. 2015. Single-cell protein production through microbial conversion of lignocellulosic residue (wheat bran) for animal feed. Journal of the Institute of Brewing 121(4):553-557. doi:10.1002/jib.251. 